\title{
USING STUDY TIMES FOR IDENTIFYING TYPES OF LEARNERS IN A DISTANCE TRAINING FOR TRAINEE TEACHERS
}

\author{
Dr. Klaus D. STILLER \\ ORCID: 0000-0002-9636-4516 \\ Department of Educational Science, University of Regensburg \\ Regensburg, Germany \\ Dr. Regine BACHMAIER \\ ORCID: 0000-0002-3479-5759 \\ Computer Center, University of Regensburg \\ Regensburg, Germany
}

Received: 30/04/2018 Accepted: 05/09/2018

\begin{abstract}
One focus of distance learning research is to explore the extent that learner characteristics and skills determine learning outcomes and to elaborate predictive models of performance. Modern approaches can benefit from objective data, such as various time indices and frequencies of learner actions, provided by log systems catching online traces to identify learners that are in threat of performance loss. This approach might result in better online diagnostics and intervention methods when the mechanisms behind log data are known. Following this idea, the current study gained objective and subjective study time parameters and explored how study time is connected to learner characteristics and learning by using a script-based modularized distance-training course about media education. Data was collected from 379 trainee teachers. Given a calculated workload of 60-90 min per training module, students were clustered into two groups: learners having spent less than $25 \mathrm{~min}$ for at least one of their completed modules $(\mathrm{n}=118$; short study time group) and learners having spent more than $25 \mathrm{~min}$ for each completed module ( $\mathrm{n}=261$; long study time group). The first goal was to investigate the extent that study time is relevant for learning process and success. Groups were compared in their ratings of content difficulty, difficulty of studying, invested effort, and experienced pressure while learning, and their test performance. Differences between groups were found in all variables. The long study time learners experienced less content difficulty, studying difficulty, and pressure while learning, but reported more effort and showed higher performance. The second goal was to explore the effect of learner characteristics on study time. Groups were compared in their domain-specific prior knowledge, intrinsic motivation, computer attitude, computer anxiety, and use of learning strategies. Long study time learners showed a higher level of motivation, competences in metacognitive learning strategies, and strategy use for arranging an adequate learning environment. These findings revealed that study time is indicative of problematic students that could be targets for interventions.
\end{abstract}

Keywords: Distance training, student characteristics, self-regulated learning, cognitive load, distancelearning performance.

\section{INTRODUCTION}

Distance and online learning research intensively investigates the two major persisting problems of student dropout (e.g., Grau-Valldosera \& Minguillón, 2014; Hart, 2012; Lee \& Choi, 2011) and identifying factors that foster successful student learning (Lee \& Hao, 2015; Morris, Finnegan, \& Wu, 2005; Rowe \& Rafferty, 
2013; Trespalacios \& Rand, 2015; Tsai, 2011a, 2011b, 2015). One research focus is to explore the extent that learners' characteristics and skills determine dropout decisions (e.g., Hart, 2012; Lee \& Choi, 2011; Lee, Choi, \& Kim, 2013; Wladis, Hachey, \& Conway, 2014) and learning outcomes (e.g., Nakayama, Mutsuura, \& Yamamoto, 2014; Roblyer \& Marshall, 2003; Roblyer, 2008; Yukselturk \& Bulut, 2007) and to elaborate predictive models of dropout (e.g., Yukselturk, Ozekes, \& Türel, 2014) and performance (e.g., Akcapınar, Altun, \& Askar, 2015). Although these approaches often start with diagnostics of learner characteristics before learning (e.g., Yukselturk et al., 2014), diagnostic methods applied while learning are becoming more popular (Akcapınar, 2015a, 2015b; Akcapınar et al., 2015; Kinnebrew, Loretz, \& Biswas, 2013; Lile, 2011). Modern approaches use (educational) data mining and learning analytics to identify learners that have learning problems and are in threat of failure (Akcapınar, 2015a, 2015b; Akcapınar et al., 2015; Lile, 2011; Siemens \& Baker, 2012; Yukselturk et al., 2014), and these approaches try to benefit from objective data that are provided by all types of log systems catching online traces (Akcapinar, 2015a, 2015b; Akcapınar et al., 2015; Kinnebrew et al., 2013; Lile, 2011). Data mining methods might result in better online diagnostics and intervention methods when the mechanisms behind usage pattern are known. Hence, researchers have recommended to relate online usage patterns to patterns of student characteristics for usage patterns to be meaningful (Akcapınar, 2015b; Jo, Park, Yoon, \& Sang, 2016).

In the current study, objective and subjective study time parameters were obtained and used to identify groups of learners in a script-based distance-training course about media education. First, the differences between user groups in learning and performance were explored to show the extent that study time is related to learning. Second, the groups were compared in empirically relevant learner characteristics for distance and online learning. The learner characteristics addressed motivational (i.e., intrinsic motivation and computer attitude), affective (i.e., computer anxiety), cognitive (i.e., domain-specific prior knowledge), and skill aspects (i.e., usage of learning strategies). This step should show the extent that these characteristics affect study time, which could indicate a starting point for adequate interventions. Our investigation was conducted against the background of self-regulated learning (Rowe \& Rafferty, 2013; Panadero, 2017).

\section{SELF-REGULATED LEARNING, LEARNING STRATEGIES, AND MOTIVATION}

According to Zimmerman (2000, p. 14), "self-regulation refers to self-generated thoughts, feelings, and actions that are planned and cyclically adapted to the attainment of personal goals." Self-regulation is commonly considered to be important in multiple areas of human functioning, not limited to learning in academic settings but particularly taken under focus in that area. The core understanding of competent learning was and still is that learners initialize and then adequately use metacognitive, cognitive, motivational, and behavioral skills (Friedrich \& Mandl, 1992; McCombs, 2017; Weinstein, Acee, \& Jung, 2011). Accordingly, self-regulated learning is also seen as a process that "involves students' intentional efforts to manage and direct complex learning activities toward the successful completion of academic goals" (Rowe \& Rafferty, 2013, p. 590).

\section{Learning Strategies}

From Pintrich's perspective (1999; Panadero, 2017), self-regulated learning includes the use of cognitive, metacognitive, and resource management strategies. Learning strategies are generally defined as activities that learners apply for perceiving, processing, and storing information (Friedrich \& Mandl, 1992). Learning strategies are thought to monitor, control, and regulate basic processes for performing a learning task such as the decoding of words and images or eye movement (Weinstein \& Mayer, 1986). Strategies of rehearsal, elaboration and organization belong to the category of cognitive strategies, which comprise all basic and complex strategies of processing information (Pintrich et al., 1993; Weinstein et al., 2011). Rehearsal strategies subsume activities that enable retention of information in memory. Rehearsal increases the likelihood of shifting information from working memory into long-term memory. The effectiveness of rehearsal strategies might not only be due to sheer repetition but also due to a prolongation of information 
availability for-maybe even unconscious-elaboration processes. Elaboration strategies aim at actively integrating new information with prior knowledge. Organizational strategies are essential for learning with complex and voluminous presentations. Learners reduce information, structure information and integrate it by, for example, grouping information. Metacognitive strategies comprise the planning, monitoring, and regulation of cognitive processes (Pintrich, 1999; Griese, 2015), that is, the planning of suitable learning procedures, including the choice of strategies and the monitoring and evaluation of the result of the executed procedures (i.e., correcting the execution of learning strategies and evaluating the approach and achievement of objectives), and the regulation of the procedural flow, including interventions for corrections. A precondition for successful metacognitive strategies is that learners possess knowledge about learning strategies and the conditions in which they can be adequately applied. Resource management comprises self-management strategies, which generally support learning and shield against various external disturbances and influences (Friedrich \& Mandl, 1992). Strategies of self-motivation, time planning, attention control, warding off alternative behavioral impulses, and creating a supporting learning environment belong to this category. The management of effort and attention is especially seen as an important factor.

Numerous studies have found that self-regulated learning is significantly connected to (academic) performance (e.g., Agustiani, Cahyad, \& Musa, 2016; Azevedo \& Cromley, 2004; Khatib, 2010; Kitsantas, Winsler, \& Huie, 2008; Musso, Kyndt, Cascallar, \& Dochy, 2012; Lynch, 2006; Namlu, 2003; Schwartz, Andersen, Hong, Howard, \& McGee, 2004; Song, Kalet, \& Plaas, 2016). Self-regulated learning is also considered a key component of successful online learning (Barnard, Lan, To, Paton, \& Lai, 2008; Delen, \& Liew, 2016; Lawanto, Santoso, Lawanto, \& Goodrigde, 2014; Rowe \& Rafferty, 2013). Understanding self-regulated online learning is even more important, because online learning environments set especially high demands on self-regulation skills to succeed in learning. In the context of online and distance learning, management skills significantly predicted dropout (Lee, Choi, \& Kim, 2013; Stiller \& Bachmaier, 2017a), especially managing time effectively (Hart, 2012; Holder, 2007; Ivankova \& Stick, 2007; Lee \& Choi, 2011; Osborn, 2001; but not Lee, Choi, \& Kim, 2013; Shin \& Kim, 1999) and having comfortable conditions for studying (Castles, 2004; Osborn, 2001; Stiller \& Bachmaier, 2017a, 2017b; but not Lee, Choi, \& Kim, 2013; Shin \& Kim, 1999). Management skills and particularly managing time and effectively organizing learning were shown to be significant predictors of learning achievement (e.g., Shin \& Kim, 1999; Tsai \& Tsai, 2003; Yukselturk \& Bulut, 2007).

\section{Surface and Deep Learning Approaches}

In this context of self-regulated learning and learning strategies, deep and surface learning approaches are discussed, which are characterized by motives and strategies (Lee, 2013). Learning approaches are not considered learner characteristics but instead intentionally adopted behavioral patterns of the learner. These approaches refer to usage patterns of learning strategies that learners exhibit while performing a specific learning task (Lee, 2013). Correspondingly, learners performing surface-learning approaches are more likely guided by extrinsic motives and strive for passing a course with minimal effort, whereas learners performing deep-learning approaches are more likely guided by intrinsic motives and strive for comprehension (Baeten, Struyven, \& Dochy, 2013; Laird et al., 2014; Lee, 2013). Deep learning approaches were shown to be correlated with higher academic performance, whereas surface learning approaches correlated negatively with academic performance (Lazarević \& Trebješanin, 2013). The corresponding pattern of results was also found with online and distance performance (Akcapınar, 2015b; Yurdugül \& Menzi Cetin, 2015; Lee, 2013). Considering the two components of learning approaches, that is, motives (deep and surface motives) and learning strategies (deep and surface strategies), similar patterns of correlations with performance have been found for motives and strategies. Deep motives and strategies correlated positively with performance and surface motives and strategies correlated negatively (Akcapınar, 2015b; Lazarević \& Trebješanin, 2013; Yurdugül \& Menzi Cetin, 2015; Lee, 2013).

\section{Motivation}

Research on motivation to learn has primarily focused on dropout rates and learning success in distance and online training. Intrinsic motivation refers to doing something because it is inherently interesting or enjoyable, whereas extrinsic motivation refers to behaviors that lead to a separable outcome (Ryan \& Deci, 
2000). Intrinsic motivation is connected to high-quality learning (Ryan \& Deci, 2000; see also results on surface and deep learning), and it might also be a central factor for successful distance learning (Jones \& Issroff, 2007). Being more intrinsically motivated might make learners more robust against learning obstacles and thus reduce the likelihood of dropping out compared to less intrinsically or extrinsically motivated students. In relation to course persistence and dropout, motivation is one of the most studied variables, and it appears to be positively correlated with course persistence and negatively correlated with dropout (e.g., Castles, 2004; Chyung, 2001; Grau-Valldosera \& Minguillon, 2014; Hart, 2012; Hartnett, St. George, \& Drone, 2011; Ivankova \& Stick, 2007; Osborn, 2001; Park \& Choi, 2009; Parker, 2003). In general, positive correlations between motivation and performance were also reported (Ali \& Franklin, 2001; Aragon, Johnson \& Shaik, 2001; Artino, 2008; Delialioglu, 2005; Frederickson, Pickett, Shea, Pelz \& Swan, 2000; Sankaran \& Bui, 2001; Waschull, 2005; Yukselturk \& Bulut, 2007). Learners more intrinsically motivated might put more resources into learning and process information more deeply (see also the results on surface and deep learning), thus contributing to a greater likelihood of successfully passing tests (Lazarević \& Trebješanin, 2013; Lee, 2013; Yurdugül \& Menzi Cetin, 2015).

\section{PRIOR KNOWLEDGE, COMPUTER ATTITUDE, AND COMPUTER ANXIETY}

\section{Prior Knowledge and Self-Regulated Learning}

The level of prior knowledge is known to predict school and academic performance (Hailikari, Katajavuori, \& Lindblom-Ylanne, 2008; Ley \& Young, 1998; Zimmerman \& Martinez-Pons, 1986) and in particular influence learning in various instructional settings such as learning with multimedia instructions (Kalyuga 2007, 2014; Song, Kalet, \& Plaas, 2016). In general, possessing prior knowledge is considered a desirable condition for learning (Chi, 2006; Ericsson, 2006). The ability to learn new information is assumed to depend on the quality and quantity of prior knowledge, that is, the knowledge already stored in long-term memory. Learning new information succeeds best when the information can be connected to available knowledge from long-term memory (van Gog, Ericsson, Rikers, \& Paas, 2005). Thus, possessing more prior knowledge allows students to relate new information more easily to the memory stores. Being able to relate new information more easily to prior knowledge and thus to expand knowledge should consequently result in better performance. But research about the expertise reversal effect also revealed instructional conditions that impair student learning despite considerable prior knowledge, although it supported novices (Kalyuga, 2014).

Prior knowledge was shown to affect performance in various educational contexts. The more students knew, the more they gained when studying. Taking the perspective on complex learning environments, such as distance and online learning environments, domain-specific prior knowledge was shown to clearly affect program usage, information processing, and performance (Amadieu, Tricot, \& Mariné, 2009; Song, Kalet, \& Plaas, 2016). Research on hypertext revealed that prior knowledge has a positive effect on various performance tasks (e.g., Amadieu et al., 2009; McDonald \& Stevenson, 1998; Stiller, 2003, 2009, in press), resulting in a positive correlation between prior knowledge and performance (Stiller, 2003, 2009, in press). Research has also shown that prior knowledge (e.g., previous GPA or academic performance) related to student performance and dropout in online and distance learning. The higher the level of prior knowledge, the higher the students' performance, and students with a lower level of prior knowledge were more likely to dropout (Castles, 2004; Cheung \& Kan, 2002; Dupin-Bryant, 2004; Jiang, Paaquette, Baker, \& ClarkeMidura, 2015; Knestrick et al., 2016; Morris et al., 2005; Osborn, 2001; Shin \& Kim, 1999; Stiller \& Bachmaier, 2017a, 2017b).

Prior knowledge has also been shown to be connected to self-regulation, that is, higher levels of prior expertise knowledge correlate with higher levels of self-regulation skills (Chi, 2006; Ericsson, 2006; Hailikari et al., 2008; Plass, Kalyuga, \& Leutner, 2010). Thus, prior knowledge and self-regulation separately contribute to explaining learning performance, but their impact on performance has been rarely investigated 
together in research (Song et al., 2016). In a recent study, Magno (2016) reported high multiple correlations of prior knowledge and self-regulation skills with academic performance in various subjects, but the details of the calculated regression analyses were not reported. The findings are not clear as to the extent that each of the seven self-regulation strategies and three prior knowledge aspects contributed most to the prediction of performance. Moreover, the regression analysis seems to be inadequately used for the sub-samples under focus (10 multiple correlations were calculated for 10 high schools, but in two instances the number of students in the sub-sample was less than the number of predictors $(=10)$, and in four instances the number of students in the sub-sample was less than double the number of predictors $(<20)$. Another recent study by Song et al. (2016) found no relationship between prior knowledge and self-regulation but significant effects of prior knowledge and selt-regulation on medical clerkship students' performance.

\section{Computer Anxiety, Computer Attitude, and Self-Regulated Learning}

Computer anxiety is considered a trait comprising affective aspects, such as feelings of anxiety, and cognitive aspects such as worrisome thoughts (Richter, Naumann, \& Horz, 2010). Attitudes are mostly viewed as being composed of affective, conative, and cognitive components (Richter et al., 2010). From a cognitive perspective, attitudes are often conceptualized as beliefs, which are organized in topics. Therefore, for distance and online learning, focusing on computer attitudes, conceptualized as a belief about the computer being useful as an instrument for working and learning that develops through self-experience (Richter et al., 2010), might be informative. Computer anxiety and computer attitude are considered to influence selfregulated learning, especially learning strategy usage. Given that computer anxiety and computer attitudes have been shown to be highly correlated (e.g., Stiller \& Köster, 2017), rationales for explaining effects on self-regulated learning are also highly overlapping.

The empirical literature has often investigated the relation between computer anxiety and computer attitudes with performance and also learning systems and computer usage by focusing on the influence of computer self-efficacy as an intermediated variable (e.g., Desai, 2001; Hauser, Paul, \& Bradley, 2012; Saadé \& Kira, 2009; Sam, Othman, \& Nordin, 2005). The prevailing underlying assumption is that computer anxiety and computer attitude directly influence self-efficacy, which then directly influence the system usage and performance. In other words, only an indirect negative effect on course usage and performance by anxiety and attitudes were assumed (Desai, 2001; Hauser, Paul, \& Bradley, 2012; Saadé \& Kira, 2009; Sam, Othman, \& Nordin, 2005). In this context, negative attitudes and a considerable level of computer anxiety might lead to a lower level of self-efficacy and hence to surface learning or inadequate usage of learning strategies. The adequate use of learning strategies is widely known to be correlated with positive computer attitudes and lack of computer anxiety (Wong, Ibrahim, \& Ayub, 2012). For example, Tsai and Tsai (2003) showed that higher order metacognitive skills (e.g., monitoring comprehension, selecting main ideas, and resource management according to Weinstein \& Palmer, 1990) were correlated with more positive computer attitudes and lower computer anxiety, Usta (2011) reported positive correlations between online selfregulated learning and attitudes towards the internet, attitudes towards web-based education and attitudes towards computers for university students taking a web-based training, and Wong et al. (2012) found positive correlations of computer attitudes with motivation (resource management) and self-regulation skills (e.g., time management, information processing, selecting main ideas and test strategy according to Weinstein \& Palmer, 1990). The correlation between self-regulated learning and computer anxiety was also demonstrated in older studies. Rakes (1992), for example, found that self-directed learners possessed less computer anxiety, and Namlu (2003) showed that a strategy training for students attending a computer programming language course also reduced computer anxiety.

Few studies have focused on how computer anxiety affects distance training dropout and persistence (e.g., Long et al., 2009; Stiller \& Köster, 2016; Stiller \& Bachmaier, 2017a, 2017b). Long et al. (2009) investigated a training course for employees of a Midwest-based landscaping company in the U.S. and found no differences between dropout students and training completers. In contrast, Stiller and Köster (2016) 
reported a higher level of computer anxiety with dropout employees compared to persisting employees, but later studies revealed no differences between dropout and persisting students in a distance teacher-training environment about media education (Stiller \& Bachmaier, 2017a, 2017b). Analogously, only a few studies have investigated the effects of computer attitudes on learning performance. The focused attitudes comprised, for example, attitudes towards computers, e-learning, internet use, information technology, and technology use. These studies reported that negative attitudes had negative effects and positive attitudes had positive effects on the usage of a training environment and dropout and persistence rates (Bernard et al., 2004; Stiller, 2009, 2015b; Stiller \& Köster, 2016; but not Stiller \& Bachmaier, 2017a, 2017b). Stiller $(2009,2015 b)$ also showed that negative attitudes interact with the type of presentations used in a learning environment and how the learners navigated through the environment.

\section{USAGE DATA OF ONLINE LEARNING ENVIRONMENTS, STUDY TIME AND LEARNING}

Usage data of an online learning environment can inform educators about various aspects of learning, especially performance and threat of student dropout (Akcapınar, 2015b; Akcapınar et al., 2015; Kinnebrew et al., 2013; Jiang et al., 2015; Lile, 2011; Morris et al., 2005; Rafaeli \& Ravid, 1997; Siemens \& Baker, 2012). For example, usage patterns gained by log file analyses could be related to level of performance (Akcapinar et al., 2015; Jiang et al., 2015; Morris et al., 2005; Rafaeli \& Ravid, 1997) and surface and deep learning approaches (Akcapınar, 2015b, 2016). Akcapınar et al. (2015), for example, considered the following usage variables: number of logins, total time spent in the learning environment, number of posts, number of tags used in posts, number of other students' posts viewed, number of other students' posts assessed, number of discussion section views, number of responses to other students' questions in the discussion section, number of questions and answers viewed, and number of assessments of questions in the discussion section. The indicators, which could be used for analyses, depend on the online learning environment and the user actions that can be performed (Akcapınar, 2015b; Akcapınar et al., 2015; Jiang et al., 2015; Lile, 2011; Morris et al., 2005; Rafaeli \& Ravid, 1997; Siemens \& Baker, 2012). Studies have shown that a less intensive usage reflected by low numbers of events (e.g., logins, posts) and short event times (e.g., total time spent in the online environment) correlated with a surface learning approach and a lower level of performance, and a more intensive usage correlated with a deep learning approach (Akcapinar, 2015b, 2016) and a higher level of performance (Akcapınar, 2015b, 2016; Akcapinar et al., 2015; Morris et al., 2005; Rafaeli \& Ravid, 1997).

Among the usage-pattern variables, various time measures were shown to be indicative of learning approaches and level of performance (Akcapınar, 2015b, 2016; Akcapınar et al., 2015; Jiang, et al., 2015; Morris et al., 2005; Shin \& Kim, 1999). Morris et al. (2005) already concluded that the time spent on the learning task is important for successful online learning (besides frequency of participation). This conclusion is supported in the literature (Akcapınar, 2015b, 2016; Akcapınar et al., 2015; Jiang, et al., 2015; Lawanto et al., 2014; Morris et al., 2005; Shin \& Kim, 1999). Some studies, however, have also shown that the time spent with specific information or actions might be more indicative of successful learning than the overall time spent on studying (e.g., Jiang et al., 2015). This distinction is based on the fact that overall study time is an aggregate of various partial durations of studying different types of information or other types of actions in an educational environment. Thus, time measures are only indicative of successful learning when time measures are correlated with effective and efficient learning processes.

\section{RESEARCH OBJECTIVES AND EXPECTATIONS}

The aim of the study was to profile different groups of students based on their study time of distance training modules. Therefore, students were first clustered according to their study times (fast vs. slow) of the training modules. Then these clusters were compared on the experienced difficulties of content and learning, the invested effort, experienced pressure while learning, and performance. This first step was expected to show 
that usage groups defined by study times are meaningful entities and differ in learning experience and performance. Then the study-time clusters were compared on the learner characteristics of learning strategy usage, domain-specific prior knowledge, and computer attitude and computer anxiety. Clusters were also compared in reference to their demographic characteristics. This second step was expected to show that usage groups are meaningful entities and differ in relevant individual characteristics that influence distance learning.

\section{METHODOLOGY}

\section{Sample}

The data of 379 of the 575 trainee teachers who registered for a distance training about media education in the German federal state of Bavaria were used for this study; 196 trainee teachers dropped out of the training before completing any module. Trainee teachers were recruited by promoting the distance training via flyers that were provided to all primary schools, secondary general schools, intermediate schools, and grammar schools in Bavaria (details about the German classification of schools can be found in Federal Ministry of Education and Research, 2016). The students of the sample had completed at least one of the eight modules of the distance training by taking the final module test; none of the 196 excluded trainee teachers completed any of the final module tests. The mean age of trainees was 26.62 years $(S D=3.19$, range from 22 to 49 years, $n=378)$. Most trainees worked in intermediate and grammar schools $(35.62 \%$ and $28.23 \%)$, followed by primary and secondary general schools $(22.16 \%$ and $13.46 \%)$. Only two trainees worked in other school types $(0.53 \%)$.

\section{Description of the Distance Training}

The training was based on a modular design and instructional texts. Students could learn at their own pace and at any time; they could freely decide how many of the modules they wanted to study and in which sequence. The starting point of the training was a Moodle course portal. It consisted of nine modules, an introductory module, and eight modules about media education (e.g., Where to find what in the Web useful web search, Risks and dangers for children and adolescents in the web, Reading, what else? - Reading as a key to media literacy). The introductory module provided information about the training content, the technical requirements, the course organization, and distance learning skills. Each course module was linearly structured with six sections:

$>$ The module profile provided an overview about the content and introduced the teaching objectives.

$>$ Then, a case example of a real-life problem was presented.

$>$ A test of domain-specific prior knowledge was used for activating prior knowledge and providing the student with feedback about their level.

$>$ The instructional part comprised an instructional text and optional supporting material.

$>$ A questionnaire about studying the module was provided.

$>$ A final performance test evaluated learning success and provided feedback.

The workload for studying a module was estimated to take 60 to 90 minutes, which sums to 8 to 12 hours for the whole course. Students were supported via email, chat, and phone for questions about content or difficulties in understanding aspects of the training and for assisting with managing the organization and technology. Response to email was given within a few hours including evenings and weekends. Chat and phone consulting was provided during office hours (announced at least four weeks in advance) in the afternoon and on Saturday.

\section{Procedure and Measurements}

The training was offered during a Bavarian school year lasting from October 2009 to July 2010. Any interested trainee teacher could register. The first login directed students to the introductory module that 
could be worked through voluntarily. Whether or not the introductory module was studied, the students were asked to complete the first online questionnaire when leaving the module. Students were asked to provide demographic information and to rate various statements assessing the learner characteristics in focus. After completion, the eight distance-training modules were accessible. A prior-knowledge test was placed at the beginning of a module and a final module test at the end. Before taking the final module test, students were questioned about how they experienced studying the module. A student could provide up to eight data sets, one for each module.

The first questionnaire comprised the measurements of the following learner characteristics (see all items and measurement scales in the appendix):

$>$ The intrinsic motivation to participate in the distance training was measured by the Interest/Enjoyment scale of the Intrinsic Motivation Inventory (Ryan et al., 1982).

$>$ Computer attitude was assessed by the scale "Personal experience/learning and working/autonomous entity" of the Questionnaire for the Content-Specific Measurement of Attitudes toward the Computer (Richter et al., 2010). The items of the scale are statements about the personal experience with using the computer as a means for learning and working. The negative component of computer attitude (i.e., the sense of the computer being regarded as an uncontrollable machine) was examined (Richter et al., 2010).

$>$ Computer anxiety was assessed by the scale "Confidence in dealing with computers and computer applications" of the Questionnaire for the Content-Specific Measurement of Attitudes toward the Computer (Richter et al., 2010).

$>$ Skills in using learning strategies were assessed by adapting three scales of the Questionnaire for Measuring Learning Strategies of Students (Wild \& Schiefele, 1994): metacognitive learning strategies (planning, monitoring, and regulating), time management strategies, and strategies to arrange an adequate learning environment.

Individual scores of the above listed learner characteristics were calculated as means of scale items. This procedure resulted in scores ranging from 1 to 5 . A higher individual score expresses a higher level of the learner characteristic except for computer attitude, which indicates a low negative attitude (a higher score could be vaguely interpreted as a "positive" attitude).

The module questionnaires comprised four subjective ratings of various learning aspects.

$>$ The effort put into learning by the students was measured by the Effort/Importance scale of the Intrinsic Motivation Inventory (Ryan et al., 1982).

$>$ The pressure experienced by the students while learning was assessed by the Pressure/Tension scale of the Intrinsic Motivation Inventory (Ryan et al., 1982).

$>$ Difficulty of contents was rated by a one-item measure often used for measuring intrinsic cognitive load against the background of cognitive load theory (de Jong, 2010).

$>$ Difficulty of studying was also rated by a one-item measure often used for measuring overall cognitive load against the background of cognitive load theory (de Jong, 2010).

Individual scores were calculated as means of the module scores (from one to eight module mean scores). Per module, the module scores of the multiple-item scales (i.e., Effort/Importance and Pressure/Tension) were calculated as the mean of items. The single-item difficulty measures were used as rated. This procedure resulted in individual score range of 1 to 5 . A higher individual score expresses a higher level of invested effort, experienced pressure and tension while learning, content difficulty, and studying difficulty.

During each module, prior knowledge was also assessed with a 5-item, multiple-choice test and performance with a 15-item multiple-choice test (including the five items of the pre-test). Each item comprised four answers of which at least one was correct. Prior-knowledge and performance scores were calculated as percent 
correct. Multiple-choice tests were considered to be appropriate instruments for measuring learning success, because the training was intended to provide factual knowledge. Like the individual scores of the module ratings, the individual prior-knowledge and performance scores were calculated as means over the available completed modules.

\section{RESULTS}

Two groups were formed from the 379 students who completed at least one of the modules' final tests (successfully or not) based on (1) study time of modules, (2) self-reported study time, and (3) proportion of short versus long study time. The criteria are described in the following paragraphs.

$>$ Objective study time measure of modules: The time period between completing the prior knowledge test and starting the final module test was used as an indicator of study time of modules. This period was only valid when learning continued after completing the prior knowledge test. Objective study time measures should be reliable for detecting short study times by comparing measured time periods to a set criterion, even when learning breaks are included in the measure. The criterion to classify study time per module as short or long was set to $20 \mathrm{~min}$. This criterion was chosen, because a successful completion of any module was calculated with a workload of 60 to $90 \mathrm{~min}$ and $20 \mathrm{~min}$ or less could be seen as a very fast work-through of modules.

> Self-reported study time of modules: Objective study time measures are not reliable measures when periods are longer. When learners download a module script after completion of the prior knowledge test and study the script at various times throughout a long period, this measure is not reliable. For example, some registered measures were even as long as weeks, which likely included numerous breaks. Accordingly, when the objective registered period exceeds $30 \mathrm{~min}$. in this study, the selfreported study time was used as an indicator of study time with the criterion set to $25 \mathrm{~min}$. We assumed that students could reliably rate short study times.

$>$ Proportion of short to long module study times: Learners having studied at least one of the studied modules with a short study time were classified as short study time learners, otherwise learners were classified as long study-time learners.

This process resulted in a group of 261 long study time learners who completed all of their studied modules with an estimated study time of more than 25 min and a group of 118 short study time learners who completed at least one module with an estimated study time of less than $25 \mathrm{~min}$. About $41 \%$ of the short study-time students studied most of their modules fast, about $47 \%$ of the students studied more of their completed modules above $25 \mathrm{~min}$, and about $12 \%$ studied as many modules in a short study time as in a long study time.

Table 1 . The percentage of students working on modules in short or long study times.

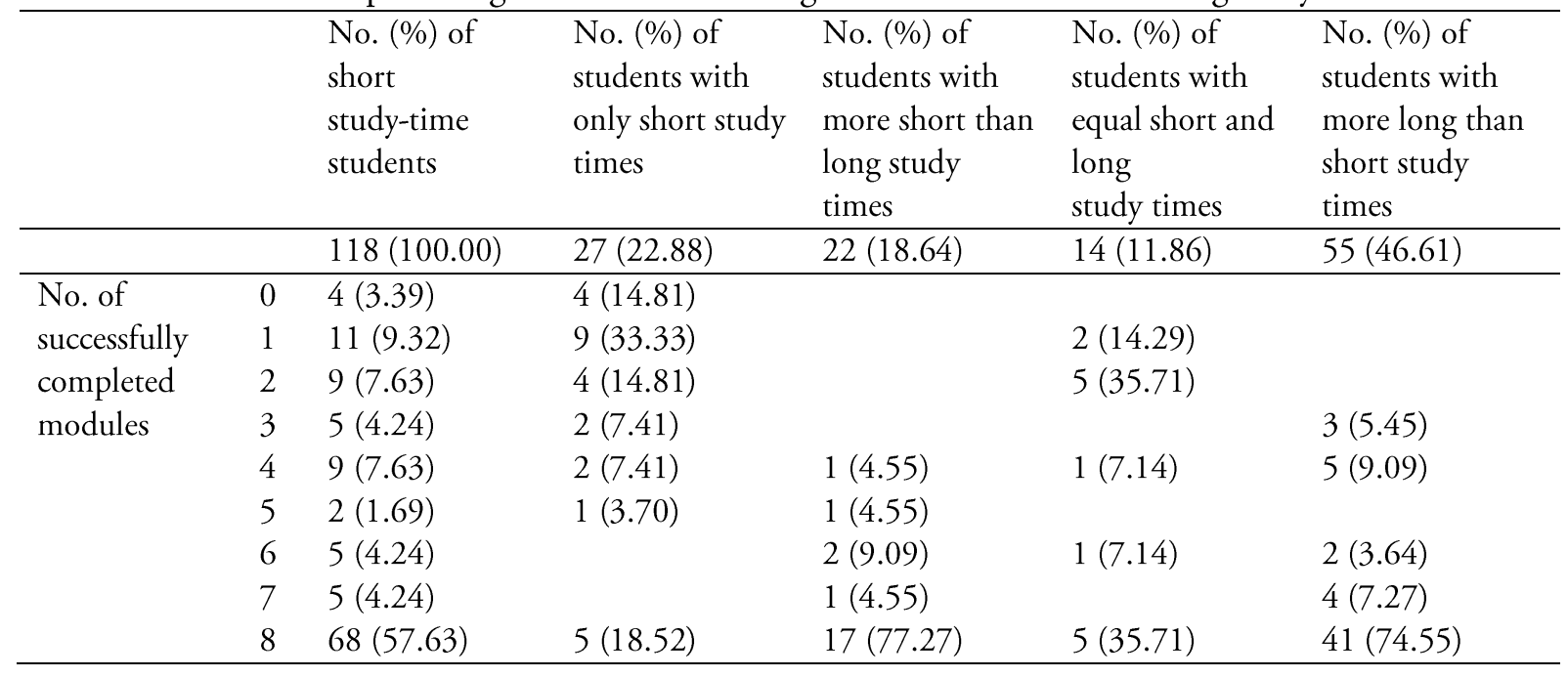


First, no differences were found between the study time groups on age and type of school (see Tables 2 and 3), but difference were found for gender and the number of successfully completed modules (for the analysis, the categories of 0-3 and 4-7 completed modules formed one group each). The long study-time students mostly completed only one or two (39.08\%) or all modules (48.28\%) but rarely three to seven modules $(11.12 \%)$. The short study-time students also mostly completed all modules $(57.63 \%)$ but showed no clear pattern for completing a specific number of modules when all eight were not completed. The proportion of male students was higher in the short study time group.

Table 2. The demographic characteristics of the trainee teachers.

\begin{tabular}{|c|c|c|c|c|c|c|c|}
\hline & & $\begin{array}{l}\text { No. (\%) of } \\
\text { studying } \\
\text { students }\end{array}$ & $\begin{array}{l}\text { No. (\%) of } \\
\text { short study- } \\
\text { time students }\end{array}$ & $\begin{array}{l}\text { No. (\%) of } \\
\text { long } \\
\text { study-time } \\
\text { students }\end{array}$ & $\lambda^{2}$ & $d f$ & $p$ \\
\hline & Total & $379(100.00)$ & $118(31.13)$ & $261(68.87)$ & & & \\
\hline Sex & Female & $279(73.61)$ & $78(66.10)$ & $201(77.01)$ & 4.98 & 1 & .026 \\
\hline & Male & $100(26.39)$ & $40(33.90)$ & $60(22.99)$ & & & \\
\hline Type of & Primary school & $84(22.16)$ & $25(21.19)$ & $59(22.61)$ & 1.85 & 4 & $\mathrm{~ns}$ \\
\hline school & $\begin{array}{l}\text { Secondary general } \\
\text { school }\end{array}$ & $51(13.46)$ & $14(11.86)$ & 37 (14.18) & & & \\
\hline & Intermediate school & $135(35.62)$ & $46(38.98)$ & $89(34.10)$ & & & \\
\hline & Grammar school & $107(28.23)$ & $33(27.97)$ & $74(28.35)$ & & & \\
\hline & Other than listed & $2(0.53)$ & & $2(0.77)$ & & & \\
\hline No. of & 0 & $8(2.11)$ & $4(3.39)$ & $4(1.53)$ & 18.29 & 2 & .001 \\
\hline successfully & 1 & $77(20.32)$ & $11(9.32)$ & $66(25.29)$ & & & \\
\hline completed & 2 & $45(11.87)$ & $9(7.63)$ & $36(13.79)$ & & & \\
\hline modules & 3 & $15(3.96)$ & $5(4.24)$ & $10(3.83)$ & & & \\
\hline & 4 & $17(4.49)$ & $9(7.63)$ & $8(3.07)$ & & & \\
\hline & 5 & $10(2.64)$ & $2(1.69)$ & $8(3.07)$ & & & \\
\hline & 6 & $7(1.85)$ & $5(4.24)$ & $2(0.77)$ & & & \\
\hline & 7 & $6(1.58)$ & $5(4.24)$ & $1(0.38)$ & & & \\
\hline & 8 & 194 (51.19) & $68(57.63)$ & $126(48.28)$ & & & \\
\hline
\end{tabular}

To assess whether differences between study time groups on learner characteristics, study ratings, and performance were affected by gender differences and the number of completed modules, an ANCOVA was computed with the number of completed modules as covariate, gender and study time as independent variables, and learner characteristics as the dependent variable. A multivariate ANCOVA was also computed with the same covariate and independent variables but with ratings and performance as dependent variables.

Number of completed modules was not related to learner characteristics (Pillai's trace $=.013, F(7,368)=.69, p$ $=.679$, partial $\eta^{2}=.013$ ). Although gender showed to be a significant factor for learner characteristics (Pillai's trace $=.101, F(7,368)=5.91, p<.001$, partial $\left.\eta^{2}=.101\right)$, no significant interaction with study time could be found (Pillai's trace $=.014, F(7,368)=.76, p=.621$, partial $\eta^{2}=.014$ ). Study time groups differed concerning learner characteristics (Pillai's trace $=.047, F(7,368)=2.59, p=.013$, partial $\eta^{2}=.047$ ).

In contrast with the first analysis, the number of completed modules was related to study ratings and performance (Pillai's trace $=.157, F(5,352)=13.14, p<.001$, partial $\left.\eta^{2}=.157\right)$, but then the same pattern appeared for study ratings and performence. Gender was a significant factor (Pillai's trace $=.033, F(5,352)=2.41, p=.036$, partial $\eta^{2}=.033$ ), but no significant interaction with study time could be found (Pillai's trace $=.002, F(5,352)=.15, p$ $=.981$, partial $\eta^{2}=.002$ ). Study time groups also differed concerning study ratings and performance (Pillai's trace $=.109, F(3,352)=8.62, p<.001$, partial $\left.\eta^{2}=.109\right)$.

After pre-analyses, the two study time groups were compared on the learner characteristics, the study ratings and performance. No significant differences were found for prior knowledge, computer attitude, computer anxiety, and time management but for intrinsic motivation, metacognitive learning strategies, and using 
strategies for arranging a learning environment. Long study-time learners showed a higher level of motivation, competences in metacognitive learning strategies and usage of strategies for arranging ones learning environment. Generally, only small effects were found. For study ratings, long study-time learners reported lower levels of difficulty of contents, difficulty of studying, and pressure/tension and a higher level of effort/importance than short study-time students. In addition, long study-time learners performed better than short study-time students. Small to medium effect sizes were found.

Table 3. Means and standard deviations of the student groups, results and effect sizes are shown.

\begin{tabular}{|c|c|c|c|c|c|c|c|c|c|c|}
\hline & \multicolumn{3}{|c|}{$\begin{array}{r}\text { Short study-time } \\
\text { students }\end{array}$} & \multicolumn{3}{|c|}{$\begin{array}{r}\text { Long study-time } \\
\text { students }\end{array}$} & \multirow[b]{2}{*}{$t$} & \multirow[b]{2}{*}{$d f$} & \multirow[b]{2}{*}{$p$} & \multirow[b]{2}{*}{$d$} \\
\hline & $M$ & $S D$ & $n$ & $M$ & $S D$ & $n$ & & & & \\
\hline age & 26.60 & 2.85 & 117 & 26.63 & 3.34 & 261 & -.10 & 259.29 & ns & -.01 \\
\hline Intrinsic motivation & 3.80 & .61 & 118 & 3.98 & .59 & 261 & -2.57 & 220.04 & .011 & -.29 \\
\hline Computer attitude & 3.95 & .77 & 118 & 3.95 & .70 & 261 & .03 & 207.71 & ns & .00 \\
\hline Computer anxiety & 2.09 & .75 & 118 & 2.09 & .68 & 261 & -.05 & 207.82 & ns & -.01 \\
\hline Metacog. strategies & 3.44 & .59 & 118 & 3.58 & .52 & 261 & -2.13 & 200.29 & .034 & -.25 \\
\hline Time management & 2.66 & .98 & 118 & 2.66 & .95 & 261 & -.03 & 220.49 & ns & .00 \\
\hline Learning environment & 3.93 & .63 & 118 & 4.18 & .61 & 261 & -3.52 & 221.57 & .001 & -.39 \\
\hline Prior knowledge & 51.57 & 12.33 & 118 & 49.62 & 12.83 & 261 & 1.41 & 234.41 & ns & .15 \\
\hline Difficulty of contents & 2.02 & .66 & 111 & 1.69 & .63 & 250 & 4.51 & 201.91 & .001 & .52 \\
\hline Difficulty of studying & 1.94 & .74 & 111 & 1.66 & .66 & 250 & 3.39 & 190.85 & .001 & .40 \\
\hline Effort/Importance & 3.23 & .46 & 111 & 3.52 & .51 & 250 & -5.28 & 232.43 & .001 &,- 58 \\
\hline Pressure/Tension & 2.04 & .68 & 111 & 1.81 & .69 & 250 & 2.92 & 213.75 & .004 & .33 \\
\hline Performance & 79.17 & 12.42 & 118 & 84.07 & 10.51 & 261 & -3.73 & 195.85 & .001 & -.44 \\
\hline
\end{tabular}

\section{DISCUSSION}

The aim of the study was to identify different groups of students based on their study time of distance training modules. We investigated whether study time was related to learning experience and performance and also to student characteristics. Student groups could be successfully identified according to study time. These groups were shown to be meaningful entities, because they differed in learning experience and performance. Student groups were also shown to be meaningful entities in terms of student characteristics.

Two learner groups were formed by focusing on study time per modules. One group completed most of their modules very fast, indicating that they had not spent much time studying the instructional texts. Thus, students likely missed important information that could not be organized and integrated into an adequate knowledge representation. They were assumed to have performed only surface learning. Students from the second group spent reasonably long periods for studying, which allowed adequate processing time (e.g., selection, organization, and integration) of important information to build a knowledge representation. They were assumed to have performed deeper learning.

Evidence for these assumptions was found in the analysis of the learning experience and performance. A clear pattern appeared showing that long study-time learners reported a higher level of effort and importance and lower levels of content difficulty, studying difficulty, and pressure and tension than short study-time learners (Stiller, Petzold, \& Zinnbauer, 2011). These aspects are explainable from the perspective of study time. Short study-time learners did not invest adequate time that could have resulted in a lower level of reported invested effort and in a higher level of reported pressure and tension. Superficial studying might also have led to a higher rating of difficulty of content, because they had less time to master the content (i.e., realizing all relevant content elements and their interrelations). Therefore, the difficulty of learning is generally rated higher when spending less time for learning. 
Evidence was also found for differences in learner characteristics. Study time groups differed in learning skills and motivation, but overall effects were small. These findings correspond widely to results concerning learning skills (Castles, 2004; Hart, 2012; Holder, 2007; Ivankova \& Stick, 2007; Lee \& Choi, 2011; Lee et al., 2013; Osborn, 2001; Shin \& Kim, 1999) and intrinsic motivation (Castles, 2004; Chyung, 2001; Grau-Valldosera \& Minguillon, 2014; Hart, 2012; Ivankova \& Stick, 2007; Osborn, 2001; Park \& Choi, 2009; Parker, 2003). Learners spending more time with studying reported to be more motivated. Overall, this pattern makes sense, because intrinsic motivation is inherently linked to self-motivated learning (Ryan \& Deci, 2000). In addition, skills were also higher with long study-time students. These students might have brought more adequate metacognitive skills and skills in arranging a learning environment and could thus engage in deeper processing while studying. No differences in computer attitude, computer anxiety, time management skills, and prior knowledge were found between the two study-time groups.

\section{CONCLUSION}

Overall, the results must be interpeted carefully. Although the sample size was not small, the modular design of the distance training, the use of instructional downloadable pdf papers, and the special target group of teachers might be a concern that does not allow to generalize conclusions, especially not to whole online or distance study programs. Nevertheless, the current findings do not contradict the theoretical approach nor the empirical evidence reported in the literature.

Study times could be used to predict students' learning approaches and thus for identifying students who might need support with their studying (Akcapınar, 2015b, 2016; Akcapınar et al., 2015; Morris et al., 2005; Rafaeli \& Ravid, 1997). Selt-reported study times might be especially important to use when log files cannot be used for calculating study times, for example, when access rights have not been granted by the institution or when $\log$ files do not contain this kind of information as with distance learning courses that provide offline instructional material. In general, when log files can be used there are further indicators likely to exist that are related to learning approaches (Akcapınar, 2015b, 2016; Akcapınar et al., 2015; Kinnebrew et al., 2013; Jiang et al., 2015; Lile, 2011; Morris et al., 2005; Rafaeli \& Ravid, 1997; Siemens \& Baker, 2012). The data used in this study were obtained through the Moodle system and placed in tables that protocolled the timestamp of access to certain system pages. Even self-reported study times seem to be useful.

A special problem might arise from offering free distance and online trainings like the training in this study. The free training could invite students with a wide range of motives that lead to course registration and subsequently to participation. Consequently, identifying which students are willing to diligently study and complete the course and which students need interventions could be difficult. For example, the present training might have forced a gambling behavior of students, because the hurdle to complete a module and pass the test was set low (multiple-choice items assessing mostly factual knowledge were generally of low to medium difficulty). Thus, students could try their luck by guessing on module tests. A more challenging task might have shifted learners to dropping out when using, for example, transfer tasks or practical tasks that afford understanding of contents or presentation of skills (Stiller \& Köster, 2016; Stiller \& Bachmaier, 2017b). Normally, such tasks cannot be solved by guessing. Future research could first identify user groups and analyze them separately to gain clearer insights about which factors lead to dropout and learning success.

For practice and research, combining log file analyses with an initial diagnostics of relevant learner characteristics and learners' framework conditions for studying seems to be a promising method (Akcapınar, 2015b; Akcapınar et al., 2015; Kinnebrew et al., 2013; Lile, 2011; Yukselturk et al., 2014). Log file analyses could especially be used to support students in their learning behavior and to augment performance (Akcapınar, 2015b; Akcapınar et al., 2015; Kinnebrew et al., 2013; Lile, 2011). The analysis might also be used to identify and support students before dropping out after having studied parts of a training. Obtaining information about students' learning skills and motivation for learning at the beginning of studying could 
also help identify early dropout students (Yukselturk et al., 2014). In more complex educational environments within study programs, academic background, GPS, or former online experience and distance learning experience and success could be assessed for additional analyses (Wladis et al., 2014; Lee \& Choi, 2011).

\section{BIODATA and CONTACT ADDRESSES of AUTHORS}

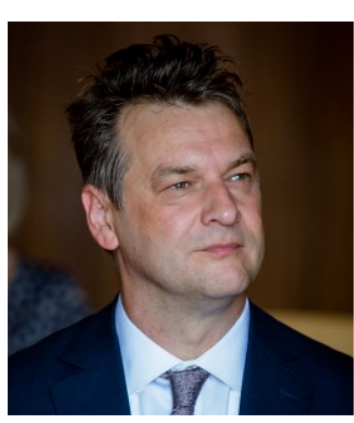

Klaus Dieter STILLER currently works as a researcher and lecturer in the Department of Educational Science at the University of Regensburg, Germany. He holds a diploma in psychology and completed his Ph.D. (Dr. phil.) on pictures and texts in multimedia learning environments. In 2006, he obtained his postdoctoral qualification (Habilitation) from his work on modes of text presentation and access to text in computerized learning environments. His interests include learning with illustrations, instructional design, distance and online learning, digital game-based learning, academic procrastination, and teacher training. He has over 20 articles published in journals in international indexes or conference proceedings, two books and 17 book chapters, and over 50 papers presented at national and international conferences.

Dr. Klaus D. STILLER

Department of Educational Science

Address: University of Regensburg, 93040 Regensburg, Germany

Phone: +499419433719

E-mail: klaus.stiller@ur.de

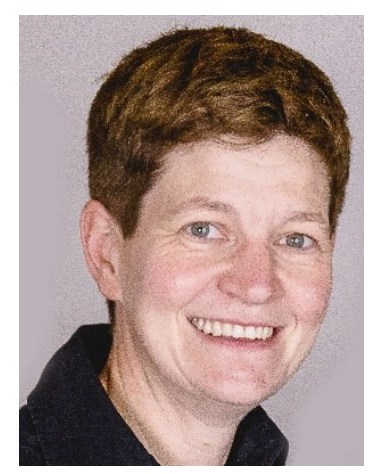

Regine BACHMAIER is the head of the IT Trainings Department at the Computer Center, University of Regensburg, Germany. She studied teaching for intermediate schools, which she completed with the second state examination in 2000. After working as an in-service teacher, she managed the extension studies in media pedagogy for student teachers at the University of Regensburg from 2003 to 2011. She earned her Ph.D. in Psychology in 2011. Her academic interest areas are distance and online learning, e-learning, and the use of internet in education. She has six articles published in journals in international indexes or conference proceedings, two books and five book chapters, and over 10 papers presented at national and international conferences.

Dr. Regine BACHMAIER

Computer Center

Address: University of Regensburg, 93040 Regensburg, Germany

Phone: +499419434856

E-mail: regine.bachmaier@ur.de

\section{REFERENCES}

Agustiani, H., Cahyad, S., \& Musa, M. (2016). Self-efficacy and self-regulated learning as predictors of students' academic performance. The Open Psychology Journal, 9, 1-6. doi:

$10.2174 / 1874350101609010001$ 
Akcapinar, G. (2015a). How automated feedback through text mining changes plagiaristic behavior in online assignments. Computers \& Education, 87, 123-130. doi: 10.1016/j.compedu.2015.04.007

Akcapinar, G. (2015b). Profiling students' approaches to learning through Moodle logs. In Proceedings of MAC-ETL 2015 in Prague. Multidisciplinary Academic Conference on Education, Teaching and Learning in Prague (pp. 242-248). Prague, Czech Republic. MAC Prague consulting Ltd. Available from https://books.google.de/books?id=SkAmCwAAQBAJ\&printsec=frontcover\&hl=de\#v=onepage\& $\mathrm{q} \& \mathrm{f}=\mathrm{false}$

Akcapinar, G. (2016). Predicting students' approaches to learning based on Moodle log. In L. Gómez Chova, A. López Martínez \& I. Candel Torres (Eds.), EDULEARN16 Proceedings. 8th International Conference on Education and New Learning Technologies July 4th-6th, 2016 Barcelona, Spain (pp. 2347-2352). doi: 10.21125/edulearn.2016.1473

Akcapinar, G., Altun, A., \& Asskar, P. (2015). Modeling Students' Academic Performance Based on Their Interactions in an Online Learning Environment. Elementary Education Online, 14(3), 815-824. doi: $10.17051 /$ io. 2015.03160

Ali, A., \& Franklin, T. (2001). Internet use in the classroom: Potentials and pitfalls for student learning and teacher-student relationships. Educational Technology, 41(4), 57-59. Available from http://www.jstor.org/stable/44428684

Amadieu, F., Tricot, A., \& Mariné, C. (2009). Exploratory study of relations between prior knowledge, comprehension, disorientation and on-line processes in hypertext. The Ergonomics Open Journal, 2, 49-57. doi: 10.2174/1875934300902010049

Aragon, S. R., Johnson, S. D., \& Shaik, N. (2001). A preliminary analysis of learning style influence on student success in online vs. face-to-face environments. In B. Cope \& M. Kalantzis (Eds.), Learning for the future (pp. 3-17). Melbourne, Australia: Common Ground Publishing.

Artino, A. R. (2008). Motivational beliefs and perceptions of instructional quality: Predicting satisfaction with online training. Journal of Computer Assisted Learning, 24, 260-270. doi: 10.1111/j.13652729.2007.00258.x

Azevedo, R., \& Cromley, J. G. (2004). Does training on self-regulated learning facilitate students' learning with hypermedia? Journal of Educational Psychology, 96, 523-535. doi: 10.1037/00220663.96.3.523

Baeten, M., Struyven, K., \& Dochy, F. (2013). Student-centered teaching methods: Can they optimize students" approaches to learning in professional higher education? Studies in Educational Evaluation, 39, 14-22. doi: 10.1016/j.stueduc.2012.11.001

Bernard, R. M., Abrami, P.C., Lou, Y., Borokhovski, E., Wade, A., Wozney, L., Wallet, P.A., Fiset, M., \& Euan, B. (2004). How does distance education compare with classroom instruction? A metaanalysis of the empirical literature. Review of Educational Research, 74(3), 379-439. doi: $10.3102 / 00346543074003379$

Castles, J. (2004). Persistence and the adult learner: Factors affecting persistence in Open University students. Active Learning in Higher Education, 5(2), 166-179. doi: 10.1177/1469787404043813 
Cheung, L. L. W., \& Kan, A. C. N. (2002). Evaluation of factors related to student performance in a distance-learning business communication course. Journal of Education for Business, 77(5), $257-$ 263. doi: $10.1080 / 08832320209599674$

Chi, M. T. H. (2006). Two approaches to the study of experts' characteristics. In K. A. Ericsson, N. Charness, P. J. Feltovich, \& R. R. Hoffman (Eds.), The Cambridge handbook of expertise and expert performance (pp. 21-30). New York: Cambridge University Press.

Chyung, S. Y. (2001). Systematic and systemic approaches to reducing attrition rates in online higher education. American Journal of Distance Education, 15(3), 36-49. doi: $10.1080 / 08923640109527092$

Delen, E., \& Liew, J. (2016). The use of interactive environments to promote self-regulation in online learning: A literature review. European Journal of Contemporary Education, 15, 24-33. doi: 10.13187/ejced.2016.15.24

de Jong, T. (2010). Cognitive load theory, educational research, and instructional design: Some food for thought. Instructional Science, 38, 105-134. doi: 10.1007/s11251-009-9110-0

Delialioglu, O. (2005). Investigation of source of motivation in a hybrid course. Presented at Association for Educational Communications and Technology Annual Meeting 2005. Available from https://eric.ed.gov/?id=ED485032

Dupin-Bryant, P. (2004). Pre-entry variables related to retention in online distance education. American Journal of Distance Education, 18(4), 199-206. doi: 10.1207/s15389286ajde1804_2

Ericsson, K. A. (2006). Protocol analysis and expert thought: Concurrent verbalizations of thinking during experts' performance on representative tasks. In K. A. Ericsson, N. Charness, P. J. Feltovich, \& R. R. Hoffman (Eds.), The Cambridge handbook of expertise and expert performance (pp. 223241). New York: Cambridge University Press.

Fredericksen, E., Pickett, A., Shea, P., Pelz, W., \& Swan, K (2000). Student satisfaction and perceived learning with on-line courses: Principles and examples from the SUNY Learning Network. Online Learning, 4(2), 7-38. Available from https://onlinelearningconsortium.org/jaln_article/student-satisfaction-and-perceived-learningwith-on-line-courses-principles-and-examples-from-the-suny-learning-network-2/

Friedrich, H. F., \& Mandl, H. (1992). Lern- und Denkstrategien - ein Problemaufriß. In H. Mandl \& H. F. Friedrich (Hrsg.), Lern- und Denkstrategien. Analyse und Intervention (pp. 3-54). Göttingen: Hogrefe.

Grau-Valldosera, J., \& Minguillón, J. (2014). Rethinking dropout in online higher education: The case of the Universitat Oberta de Catalunya. The International Review of Research in Open and Distributed Learning, 15(1), 290-308. doi: 10.19173/irrodl.v15i1.1628

Griese, B., Lehmann, M., \& Roesken-Winter, B. (2015). Refining questinnaire-based assessment of STEM students' learning strategies. International Journal of STEM Education, 2:12, 12 pages. doi: 10.1186/s40594-015-0025-9 
Hart, C. (2012). Factors associated with student persistence in an online program of study: A review of the literature. Journal of Interactive Online Learning, 11(1), 19-42. Available from https://www.ncolr.org/jiol/issues/pdf/11.1.2.pdf

Hartnett, M., St. George, A., \& Dron, J. (2011). Examining motivation in online distance learning environments: Complex, multifaceted and situation-dependent. The International Review of Research in Open and Distance Learning, 12(6), 20-38. doi: 10.19173/irrodl.v12i6.1030

Hauser, R., Paul, R., \& Bradley, J. (2012). Computer self-efficacy, anxiety, and learning in online versus face to face medium. Journal of Information Technology Education: Research, 11, 141-154. doi: $10.28945 / 1633$

Hailikari, T., Katajavuori, N., \& Lindblom-Ylanne, S. (2008). The relevance of prior knowledge in learning and instructional design. American Journal of Pharmaceutical Education, 72, Article 113, 8 pages. doi: $10.5688 /$ aj 7205113

Ivankova, N. V., \& Stick, S. L. (2007). Students' persistence in a distributed doctoral program in educational leadership in higher education: A mixed methods study. Research in Higher Education, 48, 93-135. doi: 10.1007/s11162-006-9025-4

Jiang, Y., Paquette, L., Baker, R. S., \& Clarke-Midura, J. (2015). Comparing Novice and Experienced Students in Virtual Performance Assessments. In O. C. Santos, J. G. Boticario, C. Romero, M. Pechenizkiy, A. Merceron, P. Mitros, J. M. Luna, C. Mihaescu, P. Moreno, A. Hershkovitz, S. Ventura, \& M. Desmarais (Eds.), Proceedings of the 8th International Conference on Educational Data Mining (pp. 136-143). Madrid, Spain: International Educational Data Mining Society. Available from http://educationaldatamining.org/EDM2015/index.php?page=proceedings

Kalyuga, S. (2007). Expertise reversal effect and its implications for learner-tailored instruction. Educational Psychology Review, 19, 509-539. doi: 10.1007/s10648-007-9054-3

Kalyuga, S. (2014). The expertise reversal principle in multimedia learning. In R. E. Mayer (Ed.), The Cambridge handbook of multimedia learning (pp. 576-597). New York, NY: Cambridge University Press. doi: 10.1017/CBO9781139547369.028

Kinnebrew, J. S., Loretz, K. M., \& Biswas, G. (2013). A contextualized, differential sequence mining method to derive students' learning behavior patterns. Journal of Educational Data Mining, 5(1), 190-219. Available from https://jedm.educationaldatamining.org/index.php/JEDM/article/view/34

Knestrick, J. M., Wilkinson, M. R., Pellathy, T. P., Lange-Kessler, J., Katz, R., \& Compton, P. (2016). Predictors of retention of students in an online nurse practitioner program. The Journal for Nurse Practitioners, 12, 635-640. doi: 10.1016/j.nurpra.2016.06.011

Laird, T. F. N., Seifert, T. A., Pascarella, E. T., Mayhew, M. J., \& Blaich, C. F. (2014). Deeply affecting first-year students' thinking: Deep approaches to learning and three dimensions of cognitive development. The Journal of Higher Education, 85(3), 402-432. doi: 10.1080/00221546.2014.11777333 
Lazarević, D., \& Trebješanin, B. (2013). Karakteristike i činioci pristupa studiranju studenata nastavnickih fakulteta [Characteristics and factors of learning approaches of the prospective teachers]. Psihologija, 46(3), 299-314. doi: 10.2298/PSI130601006L

Lee, S. W.-Y. (2013). Investigating students' learning approaches, perceptions of online discussions, and students' online and academic performance. Computers \& Education, 68, 345-352. doi: 10.1016/j.compedu.2013.05.019

Lee, Y., \& Choi, J. (2011). A review of online course dropout research: Implications for practice and future research. Educational Technology Research and Development, 59(5), 593-618. doi: $10.1007 / \mathrm{s} 11423-010-9177-\mathrm{y}$

Lee, Y., Choi, J., \& Kim, T. (2013). Discriminating factors between completers of and dropouts from online learning courses. British Journal of Educational Technology, 44(2), 328-337. doi: $10.1111 /$ j.1467-8535.2012.01306.x

Lee, L. C., \& Hao, K. C. (2015). Designing and evaluating digital game-based learning with the ARCS motivation model, humor, and animation. International Journal of Technology and Human Interaction, 11(2), 80-95. doi: 10.4018/ijthi.2015040105

Leone, J. (2011). Intrinsic Motivation Inventory (IMI). Available from http://selfdeterminationtheory.org/intrinsic-motivation-inventory/

Ley, K., \& Young, D. B. (1998). Self-regulation behaviors in underprepared (developmental) and regular admission college students. Contemporary Educational Psychology, 23, 42-64. doi: 10.1006/ceps.1997.0956

Long, L., Dubois, C., \& Faley, R. (2009). A case study analysis of factors that influence attrition rates in voluntary online training programs. International Journal on E-Learning, 8(3), 347-359. Available from https://www.learntechlib.org/primary/p/26285/

Magno, C. (2016). The effect size of self-regulation and prior knowledge on students performance in an open high school program. The International Journal of Research and Review, 11, 39-48.

Available from https://ssrn.com/abstract $=2892190$

McCombs, B. L. (2017). Historical review of learning strategies research: strategies for the whole learner a tribute to Claire Ellen Weinstein and early researchers of this topic.

Frontiers in Education, 2:6, 21 pages. doi: 10.3389/feduc.2017.00006

McDonald, S., \& Stevenson, R. J. (1998). Effects of text structure and prior knowledge of the learner on navigation in hypertext. Human Factors, 40, 18-27. doi: 10.1518/001872098779480541

Morris, L. V., Finnegan, C., \& Wu, S. (2005). Tracking student behavior, persistence, and achievement in online courses. The Internet and Higher Education, 8(3), 221-231. doi: 10.1016/j.iheduc.2005.06.009

Nakayama, M., Mutsuura, K., \& Yamamoto, H. (2014). Impact of Learner's Characteristics and Learning Behaviour on Learning Performance during a Fully Online Course. The Electronic Journal of $\epsilon$ Learning, 12, 394-408. Available from http://www.ejel.org/volume12/issue4 
Namlu, A. G. (2003). The effect of learning strategy on computer anxiety. Computers in Human Behavior, 19, 565-578. doi: 10.1016/S0747-5632(03)00003-7

Osborn, V. (2001). Identifying at-risk students in videoconferencing and web-based distance education. American Journal of Distance Education, 15(1), 41-54. doi: 10.1080/08923640109527073

Panadero, E. (2017) A review of self-regulated learning: six Models and four directions for research. Frontiers in Psychology, 8:422, 28 pages. doi: 10.3389/fpsyg.2017.00422

Park, J.-H., \& Choi, H. J. (2009). Factors influencing adult learners' decision to drop out or persist in online learning. Educational Technology \& Society, 12(4), 207-217. Available from https://www.j-ets.net/ETS/journals/12_4/18.pdf

Parker, A. (2003). Identifying predictors of academic persistence in distance education. United States Distance Learning Association Journal, 17(1), 55-61.

Pintrich, P. R. (1999). The role of motivation in promoting and sustaining self-regulated learning. International Journal of Educational Research, 31, 459-470. doi:10.1016/S0883-0355(99)00015-4

Plass, J. L., Kalyuga, S., \& Leutner, D. (2010). Individual differences and cognitive load theory. In J. L. Plass, R. Moreno, \& R. Brünken (Eds.), Cognitive load theory (pp. 65-88). New York: Cambridge University Press. doi: 10.1017/CBO9780511844744.006

Rafaeli, S., \& Ravid, G. (1997). Online, web-based learning environment for an information systems course: Access logs, linearity and performance. Paper presented at the Information Systems Education Conference, Orlando, FL. Available from https://www.academia.edu/10803581/Online_webbased_learning_environment_for_an_information_systems_course_Access_logs_linearity_and_p erformance?auto=download

Richter, T., Naumann, J., \& Groeben N. (2000). Attitudes toward the computer: Construct validation of an instrument with scales differentiated by content. Computers in Human Behavior, 16, 473191. doi: $10.1016 / S 0747-5632(00) 00025-\mathrm{X}$

Richter, T., Naumann, J., \& Horz, H. (2010). Eine revidierte Fassung des Inventars zur Computerbildung (INCOBI-R) [A revised version of the Computer Literacy Inventory]. Zeitschrift für Pädagogische Psychologie, 24(1), 23-37. doi: 10.1024/1010-0652/a000002

Roblyer, M. D., \& Marshall, J. C. (2002). Predicting success of virtual high school students: Preliminary results from an educational success prediction instrument. Journal of Research on Technology in Education, 35, 241-255. doi: 10.1080/15391523.2002.10782384

Rowe, F. A., \& Rafferty, J. A. (2013). Instructional Design Interventions for Supporting Self-Regulated Learning: Enhancing Academic Outcomes in Postsecondary E-Learning Environments. Journal of Online Learning and Teaching, 9, 590-601. Available from http://jolt.merlot.org/vol9no4/rowe_1213.pdf

Ryan, R. M. \& Deci, E. L. (2000). Intrinsic and extrinsic motivations: Classic definitions and new directions. Contemporary Educational Psychology, 25, 54-67. doi: 10.1006/ceps.1999.1020 
Ryan, R. M. (1982). Control and information in the intrapersonal sphere: An extension of cognitive evaluation theory. Journal of Personality and Social Psychology, 43(3), 450-461. doi: $10.1037 / 0022-3514.43 .3 .450$

Roblyer, M. D. (2008). Toward practical procedures for predicting and promoting success in virtual school students. American Journal of Distance Education, 22, 90-109. doi: $10.1080 / 08923640802039040$

Saadé, R. G., \& Kira, D. (2009). Computer anxiety in e-learning: The effect of computer self-efficacy. Journal of Information Technology Education, 8, 177-191.

Sam, H. K., Othman, A. E. A., \& Nordin, Z. S. (2005). Computer self-efficacy, computer anxiety, and attitudes toward the internet: A study among undergraduates in Unimas. Educational Technology \& Society, 8, 205-219. Available from http://ir.unimas.my/id/eprint/17413

Sankaran, S. R., \& Bui, T. (2001). Impact of learning strategies and motivation on performance: a study in web-based instruction. Journal of Instructional Psychology, 28, 191-201. Available from https://www.learntechlib.org/p/95445/

Schwartz, N. H., Andersen, C., Hong, N., Howard, B., \& McGee, S. (2004). The influence of metacognitive skills on learner's memory of information in a hypermedia environment. Journal of Educational Computing Research, 31, 77-93. doi: 10.2190/JE7W-VL6W-RNYF-RD4M

Shin, N., \& Kim, J. (1999). An exploration of learner progress and drop-out in Korea National Open University. Distance Education, 20(1), 81-95. doi: 10.1080/0158791990200107

Siemens, G., \& Baker, R. S. J. d. (2012). Learning Analytics and Educational Data Mining: Towards communication and collaboration. In S. Buckingham Shum, D. Gasevic \& R. Ferguson (Eds.), $L A K$ '12 Proceedings of the 2nd International Conference on Learning Analytics and Knowledge (pp. 252-254). doi: $10.1145 / 2330601.2330661$

Song, H. S., Kalet, A. L., \& Plass, J. L. (2016). Interplay of prior knowledge, self-regulation and motivation in complex multimedia learning environments. Journal of Computer Assisted Learning, 32, 31-50. doi: 10.1111/jcal.12117

Stiller, K. (2003). Lernstrategien und Lernerfolg beim computerbasierten Wissenserwerb [Learning strategies and achievement in computer-based knowledge acquisition]. Psychologie in Erziehung und Unterricht, 50, 258-269.

Stiller, K. D. (2009). Mono- und bimodale Textpräsentationen zu Bildern in Hypermedia-Systemen [Mono- and bimodal text presentations accompanying pictures in hypermedia systems]. Psychologie in Erziehung und Unterricht, 56, 49-63. Available from https://www.reinhardtjournals.de/index.php/peu/article/view/686

Stiller, K. D. (in press). Fostering learning via pictorial access to on-screen text. Journal of Educational Multimedia and Hypermedia. 
Stiller, K. D., \& Bachmaier, R. (2017a). Dropout in an online training for in-service teachers. In A. Volungeviciene \& A. Szücs (Eds.), EDEN 2017 Annual Conference. Diversity matters! Conference proceedings (pp. 177-185). Budapest, Hungary: European Distance and E-Learning Network (EDEN).

Stiller, K. D., \& Bachmaier, R. (2017b). Dropout in an online training for trainee teachers. European Journal of Open, Distance and E-Learning, 20(1), 80-95. doi: 10.1515/eurodl-2017-0005

Stiller, K. D., \& Köster, A. (2016). Learner attrition in an advanced vocational online training: The role of e-learning experience, computer attitude, and computer anxiety. European Journal of Open, Distance and E-Learning, 19(2), 1-14. doi: 10.1515/eurodl-2016-0004

Stiller, K. D., \& Köster, A. (2017). Cognitive loads and training success in a video-based online training course. The Open Psychology Journat, 10, 81-93. doi: 10.2174/1874350101710010081

Stiller, K. D., Petzold, K., \& Zinnbauer, P. (2011). Presentation time concerning system-paced multimedia instructions and the superiority of learner pacing. Australasian Journal of Educational Technology, 27, 693-708. doi: 10.14742/ajet.v27i4.945

Trespalacios, J., \& Rand, J. (2015). Using asynchronous activities to promote sense of community and learning in an online course. International Journal of Online Pedagogy and Course Design, 5(4), 113. doi: 10.4018/IJOPCD.2015100101

Tsai, C. W. (2011a). How much can computers and internet help? A long-term study of web-mediated problem-based learning and self-regulated learning. International Journal of Technology and Human Interaction, 7(1), 67-81. doi: 10.4018/jthi.2011010105

Tsai, C. W. (2011b). Achieving effective learning effects in the blended course: A combined approach of online self-regulated learning and collaborative learning with initiation. Cyberpsychology, Behavior, and Social Networking, 14(9), 505-510. doi: 10.1089/cyber.2010.0388

Tsai, C. W. (2015). Applying web-based co-regulated learning to develop students' learning and involvement in a blended computing course. Interactive Learning Environments, 23, 344-355. doi: $10.1080 / 10494820.2013 .764323$

Tsai, M.-J., \& Tsai, C.-C. (2003). Student computer achievement, attitude and anxiety: The role of learning strategies. Journal of Educational Computing Research, 28, 47-61. doi: 10.2190/PL27TC1Q-08B2-RMCL

Usta, E. (2011). The examination of online self-regulated learning skills in web-based learning environments in terms of different variables. The Turkish Online Journal of Educational Technology, 10, 278-286.

van Gog, T., Ericsson, K., Rikers, R., \& Paas, F. (2005). Instructional design for advanced learners: Establishing connections between the theoretical frameworks of cognitive load and deliberate practice. Educational Technology Research and Development, 53(3), 73-81. doi: $10.1007 / \mathrm{BF} 02504799$ 
Ward (1994). Effectiveness of a standard computer interface paradigm on computer anxiety, self-direction, efficiency, and sely-confidence. University of Florida, US: Dissertation. Available from https://archive.org/details/effectivenessofs00ward

Waschull, S. B. (2005). Predicting success in online psychology courses: Self-discipline and motivation. Teaching of Psychology, 32(3), 190-192. doi: 10.1207/s15328023top3203_11

Weinstein, C. E., \& Mayer, R. E. (1986). The teaching of learning strategies. In M. C. Wittrock (Ed.), Handbook of research on teaching: Third edition (pp. 315-327). New York, NY: Macmillan.

Weinstein, C. E., Acee, T. W., \& Jung, J. (2011). Self-regulation and learning strategies. New Directions for Teaching and Learning, 2011(126), 45-53. doi: 10.1002/tl.443

Weinstein, C. E., \& Palmer, D. R. (1990). Learning and study strategies inventory high school. Florida, US: H \& H Publishing Company.

Wild, K.-P., \& Schiefele, U. (1994). Lernstrategien im Studium: Ergebnisse zur Faktorenstruktur und Reliabilität eines neuen Fragebogens [Learning strategies of university students: Factor structure and reliability of a new questionnaire]. Zeitschrift für Differentielle und Diagnostische Psychologie, $15,185-200$.

Wladis, C., Hachey, A. C., \& Conway, K. M. (2014). The representation of minority, female, and nontraditional STEM majors in the online environment at community colleges: A nationally representative study. Community College Revieu, 43, 142-164. doi: $10.1177 / 0091552114555904$

Wong, S. L., Ibrahim, N., \& Ayub, A. F. M. (2012). Learning strategies as correlates of computer attitudes: A case study among Malaysian secondary school students. International Journal of Social Science and Humanity, 2, 123-126. doi: 10.7763/IJSSH.2012.V2.80

Yukselturk, E., \& Bulut, S. (2007). Predictors for student success in an online course. Educational Technology \& Society, 10(2), 71-83.

Yurdugül, H., \& Menzi Cetin, N. (2015). Investigation of the relationship between learning process and learning outcomes in e-learning environments. Eurasian Journal of Educational Research, 59, 5774. doi: $10.14689 /$ ejer.2015.59.4

Zimmerman, B. J., \& Martinez-Pons, M. (1986). Development of a structured interview for assessing student use of self-regulated learning strategies. American Educational Research Journal, 23, 614628. doi: 10.3102/00028312023004614

Zimmerman, B. J., \& Schunk, D. H. (Eds.). (2001). Self-regulated learning and academic achievement: Theoretical perspectives. Hillsdale, NJ: Erlbaum. 


\section{APPENDIX}

\section{Original German Items of the Questionnaires Used for Assessment}

Table A. Items assessing intrinsic motivation, computer attitude, and computer anxiety were rated on 5point Likert scales from "stimme nicht zu" to "stimme zu"

\begin{tabular}{ll}
\hline Intrinsic motivation (scale "Interest/Enjoyment" by Ryan et al., 1982) \\
\hline 1 & Ich denke, dass mir die Bearbeitung der Module sehr gefallen wird. \\
2 & Ich denke, dass es mir sehr viel Spaß machen wird, die Module zu bearbeiten. \\
3 & Ich denke, dass die Module sehr langweilig für mich sein werden. \\
4 & Ich denke, dass ich in die Bearbeitung der Module gar keine Aufmerksamkeit investieren werde. \\
5 & Ich denke, dass die Modulbearbeitung bestimmt sehr interessant für mich wird. \\
6 & Ich denke, dass die Bearbeitung der Module für mich sehr unterhaltsam wird. \\
7 & Ich denke, dass ich kein Vergnügen an der Modulbearbeitung haben werde. \\
\hline
\end{tabular}
al., 2010)

1 Um den Computer als Lernmittel zu verwenden, ist er mir zu unzuverlässig.

2 Ich ärgere mich oft darüber, dass der Computer für normale Menschen einfach nicht verstehbar ist.

3 Wenn ich am Computer arbeite, habe ich permanent Angst, er könnte „abstürzen“.

4 Die Arbeit am Computer ist oft frustrierend, weil ich diese Maschine nicht verstehe.

5 Der Computer macht manchmal Sachen, die ich nicht verstehe und nicht erklären kann.

6 Die Computerprogramme, die ich beim Lernen und Arbeiten nutze, sind manchmal schwer zu durchschauen.

7 Wenn ich am Computer arbeite, habe ich manchmal das Gefühl, das Ding macht, was es will.

8 Wenn mir mein Computer bei der Arbeit Probleme macht, fühle ich mich hilflos.

9 Ich würde mir wünschen, weniger mit Computern arbeiten zu müssen.

Computer anxiety (scale "Confidence in dealing with computers and computer applications" by Richter et al., 2010)

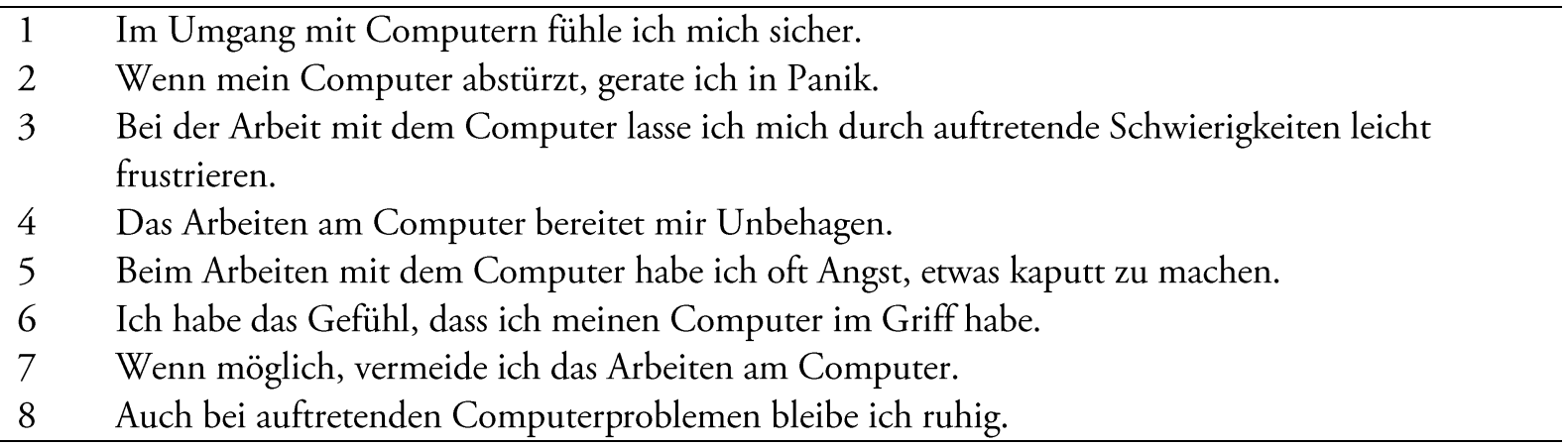

Table B. Items assessing learning skills were rated on 5-point Likert scales from "sehr selten" to "sehr oft"

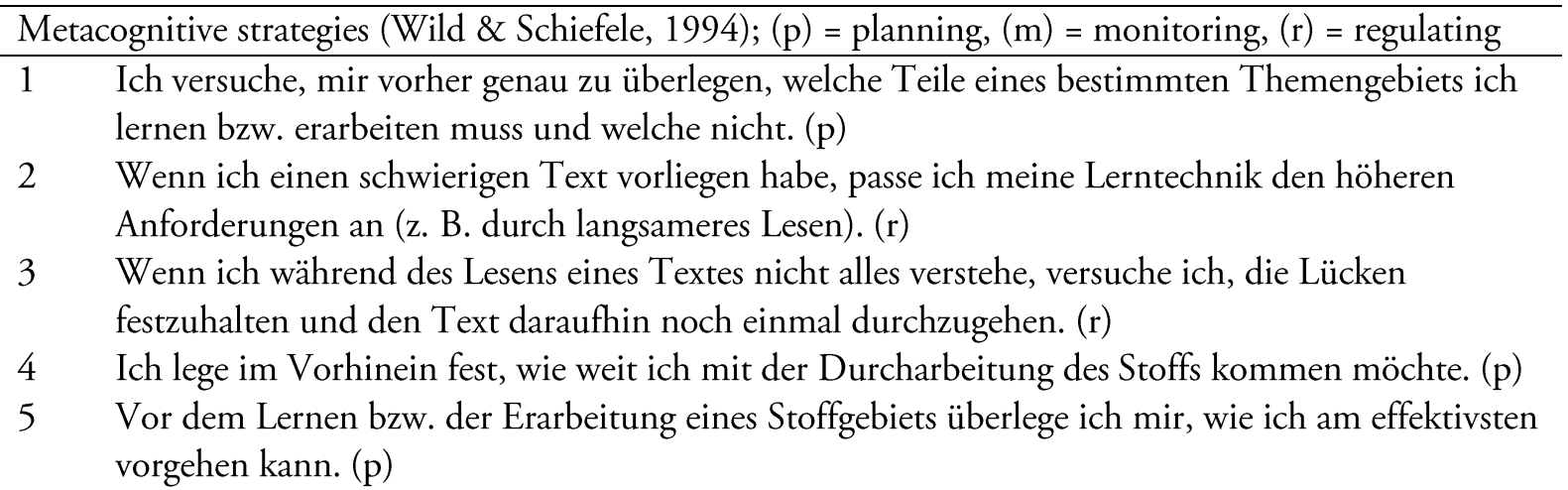


6 Ich überlege mir vorher, in welcher Reihenfolge ich den Stoff durcharbeite. (p)

$7 \quad$ Ich stelle mir Fragen zum Stoff, um sicherzugehen, dass ich auch alles verstanden habe. (m)

8 Um Wissenslücken festzustellen, rekapituliere ich die wichtigsten Inhalte, ohne meine Unterlagen zu Hilfe zu nehmen. (m)

9 Beim Lernen bzw. der Erarbeitung eines Stoffgebiets bearbeite ich zusätzliche Aufgaben, um festzustellen, ob ich den Stoff wirklich verstanden habe. (m)

10 Um mein eigenes Verständnis zu prüfen, erkläre ich bestimmte Teile des Lernstoffs einem Kollegen bzw. einem anderen Mitglied der Lerngruppe. (m)

11 Wenn mir eine bestimmte Textstelle verworren und unklar erscheint, gehe ich sie noch einmal langsam durch. (r)

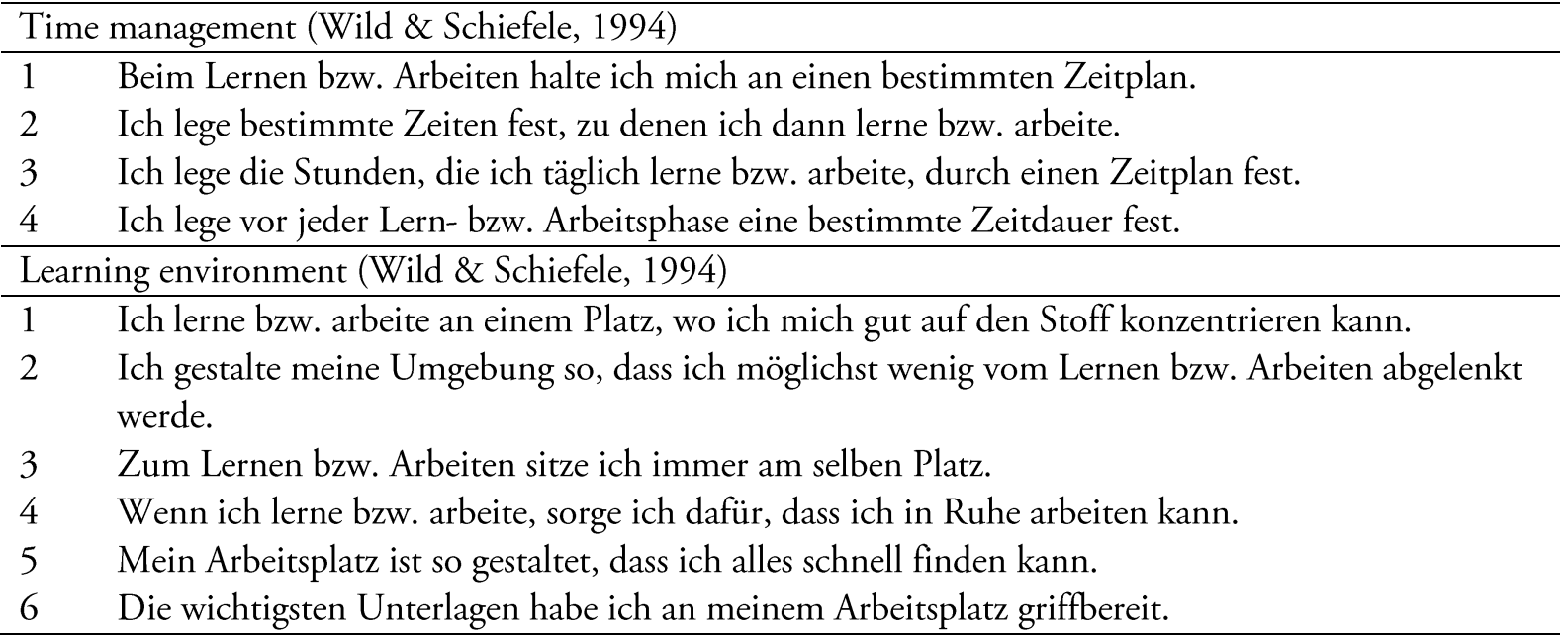

Table C. Items assessing the learning experience were rated on 5-point Likert scales from "stimme nicht zu" to "stimme zu"

\begin{tabular}{lc}
\hline \multicolumn{2}{l}{ Difficulty of content (by authors) } \\
\hline 1 & Die Inhalte des Moduls waren für mich gut verständlich. \\
\hline Difficulty of studying (by authors) \\
\hline 1 & Das Modul zu bearbeiten, war für mich sehr schwierig. \\
\hline Effort put into learning (scale "Effort/Importance" by Ryan et al., 1982) \\
\hline 1 & Ich habe viel Anstrengung in die Bearbeitung des Moduls investiert. \\
2 & Ich habe mich nicht sehr bemüht, das Modul gut zu bearbeiten. \\
3 & Ich habe mich bei der Bearbeitung des Moduls sehr bemüht. \\
4 & Es war für mich sehr wichtig, das Modul gut zu bearbeiten. \\
5 & Ich habe nicht viel Energie in die Bearbeitung des Moduls investiert. \\
\hline Pressure and tension experienced by the students (scale "Pressure/Tension" by Ryan et al., 1982) \\
\hline 1 & Ich war bei der Bearbeitung des Moduls nicht aufgeregt. \\
2 & Ich fühlte mich während der Bearbeitung des Moduls sehr unter Druck. \\
3 & Ich fühlte mich während der Bearbeitung des Moduls sehr entspannt. \\
4 & Ich war während der Bearbeitung des Moduls unruhig. \\
5 & Ich fühlte mich während der Bearbeitung des Moduls sehr angespannt. \\
\hline
\end{tabular}


Translated German Items of the Questionnaires Used for Assessment

Table D. Items assessing intrinsic motivation, computer attitude, and computer anxiety were rated on 5point Likert scales from "do not agree" to "agree"

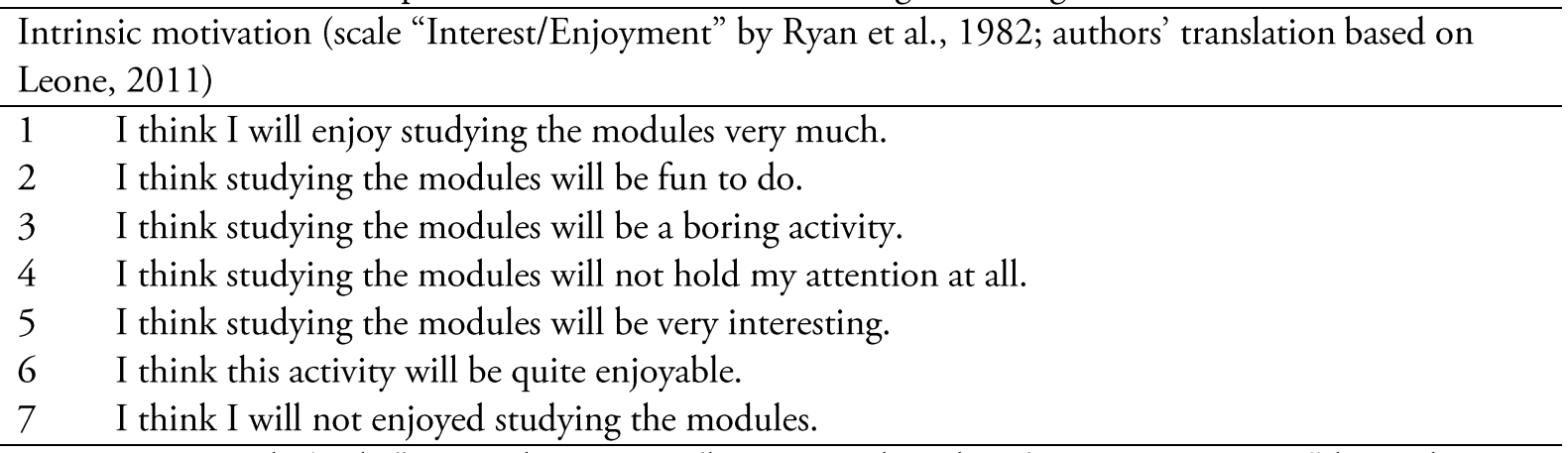

Computer attitude (scale "Personal experience/learning and working/autonomous entity" by Richter et al., 2000, 2010)

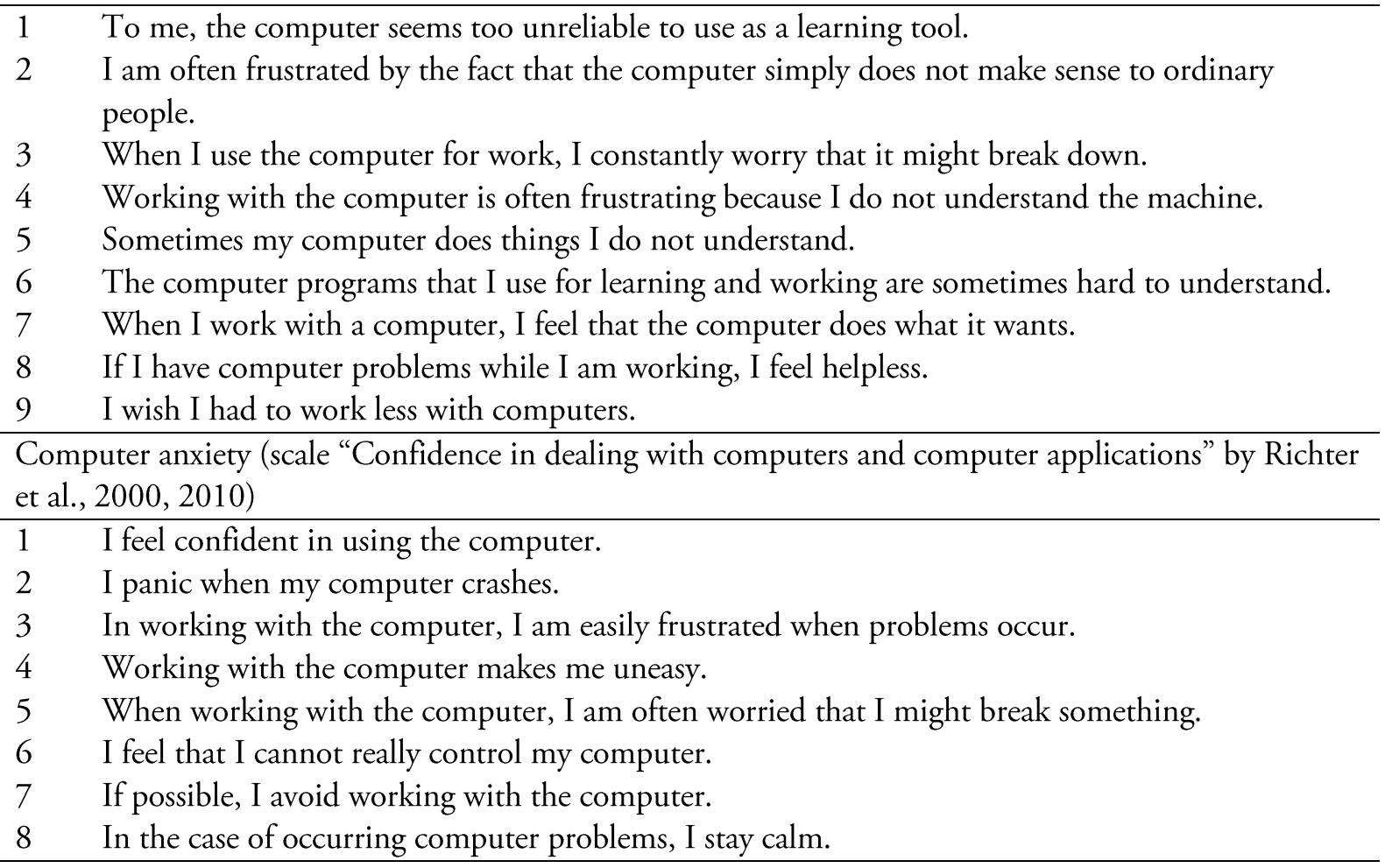

Table E. Items assessing learning skills were rated on 5-point Likert scales from "very rarely" to "very often"

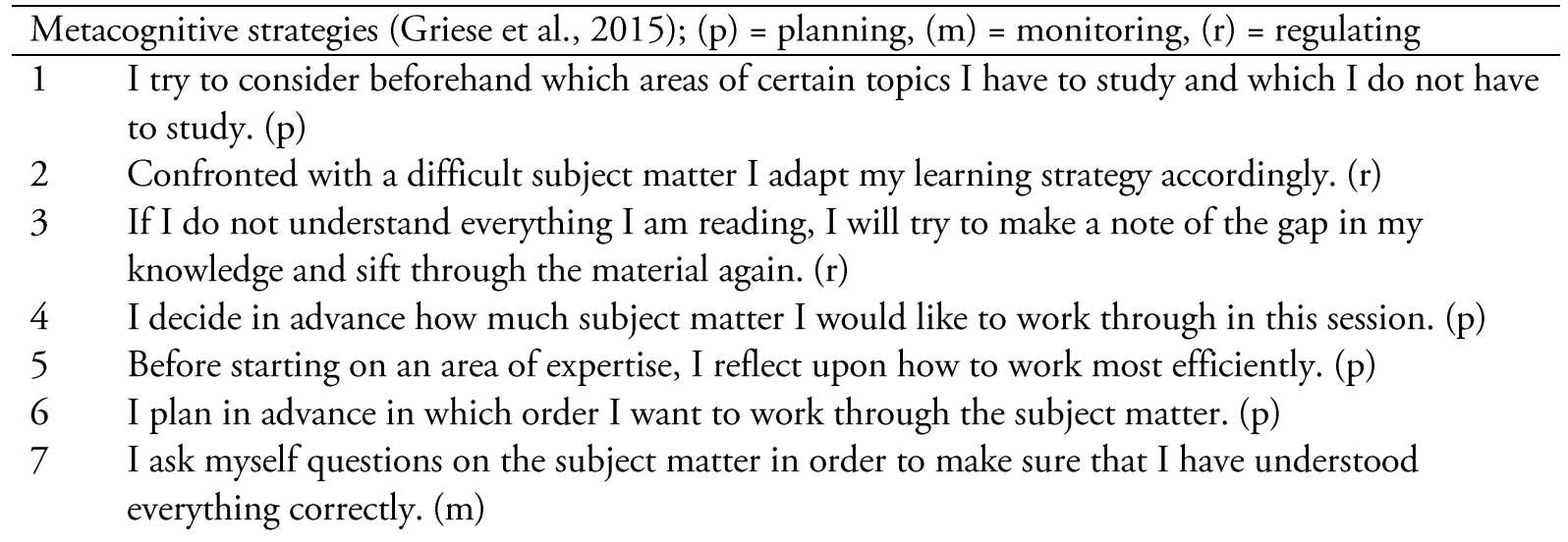


8 In order to find gaps in my knowledge I sum up the most important contents without using my notes. $(\mathrm{m})$

9 I work on additional tasks in order to determine if I have truly understood the subject matter. (m)

10 In order to check my own understanding I explain certain parts of the subject matter to a fellow student. (m)

11 When an aspect seems confusing or unclear, I examine it again thoroughly. $(\mathrm{r})$

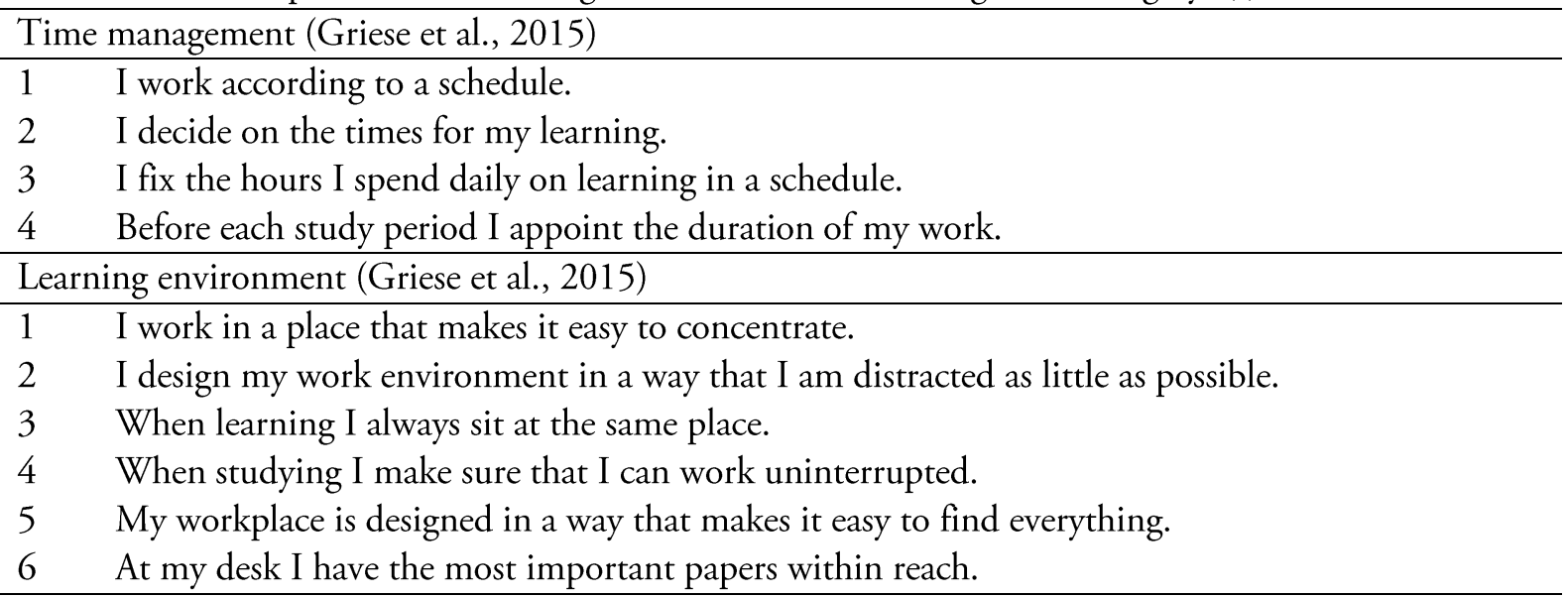

Table F. Items assessing the learning experience were rated on 5-point Likert scales from "do not agree" to "agree"

\begin{tabular}{|c|c|}
\hline \multirow{2}{*}{\multicolumn{2}{|c|}{$\begin{array}{l}\text { Difficulty of content (by authors; authors' translation) } \\
1 \quad \text { The content of the module was well comprehensible. }\end{array}$}} \\
\hline & \\
\hline \multicolumn{2}{|r|}{ Difficulty of studying (by authors; authors' translation) } \\
\hline 1 & Studying the module was very difficult for me. \\
\hline \multicolumn{2}{|r|}{$\begin{array}{l}\text { Effort put into learning (scale "Effort/Importance" by } \\
\text { on Leone, 2011) }\end{array}$} \\
\hline 1 & I put a lot of effort into processing this module. \\
\hline 2 & I didn't try very hard to do well at processing this module. \\
\hline 3 & I tried very hard on processing this module. \\
\hline 4 & It was important to me to do well at processing this module. \\
\hline 5 & I didn't put much energy into processing this module. \\
\hline \multicolumn{2}{|c|}{$\begin{array}{l}\text { Pressure and tension experienced by the students (scale "Pressure/Tension" by Ryan et al., 1982; } \\
\text { authors' translation based on Leone, 2011) }\end{array}$} \\
\hline 1 & I did not feel nervous at all while working through this module. \\
\hline 2 & I felt pressured while working through this module. \\
\hline 3 & I was very relaxed in working through this module. \\
\hline 4 & I was anxious while working through this module. \\
\hline 5 & I felt very tense while working through this module. \\
\hline
\end{tabular}

